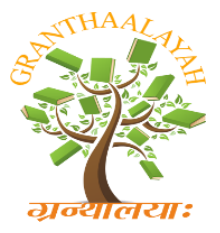

INTERNATIONAL JOURNAL OF RESEARCH GRANTHAALAYAH

A knowledge Repository

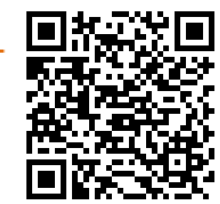

\title{
GREEN CHEMISTRY: STUDY OF ACID-BASE INDICATOR PROPERTY OF GOLDEN BEET ROOT
}

Prashant Thote

Gyanodaya Vidya Mandir, Narsingarh

\begin{abstract}
In acid- base titrations, indicators are used to show a sharp color changes at interval of pH.Natural pigments in plants are highly colored substances and may show color changes with variation of $\mathrm{pH}$. An attempt has been made to investigate the indicator activity of root extract of golden beet root and to replace the synthetic indicators as they have certain disadvantages like chemical pollution, availability problems and high cost. A study has been done to investigate the indicator activity of aqueous extract of root pigments and compared with that of already existing synthetic indicators. Pigments were extracted using hot water and a definite volume was added which gave accurate and reliable results for all the four different types of neutralization titrations - strong acid against strong base, strong acid against a weak base, weak acid against strong base and weak acid against weak base. The work proved to be acceptable in introducing root pigments as a substitute to the synthetic acid-base indicators.
\end{abstract}

Keywords:

Golden Root Beet, pH indicators, natural pigments, flower pigments, neutralization indicators, phenolphthalein substitutes.

\section{INTRODUCTION}

Beetroot is a root vegetable that grows primarily in the ground with a leafy top that grows aboveground. It can be found in both temperate and tropical areas of the world. It takes approximately 60 days from seed to harvest. Beets have been cultivated for thousands of years for their dietary value. Recent studies have indicated that consuming beetroot juice can improve certain health conditions and can also improve oxygenation during athletic activities. Though the full health effects of beetroot are not yet known, many health experts recommend consuming beetroot or beetroot herbal for a nutritional boost. Beet can be grown in all agro-ecological regions in the country. Drained soils are suitable. Ill -drained soil can cause growth problems. A pH range between 6.3 and 7.5 is most appropriate for cultivation.

The beet is derived from the wild beet or sea beet (Beta maritima) which grows on the coasts of Eurasia. 2 Ancient Greeks called the beet teutlion and used it for its leaves, both as a culinary herb and medicinally. The Indians also used the beet medicinally, but were the first to cultivate the plant for its root. They referred to the beet as beta.3 Common names for the beet include: beetroot, chard, European sugar beet, red garden beet, Harvard beet, blood turnip, maangelwurzel, mangel, and spinach beet.

The beetroot, commonly called the beet, is a biennial plant that produces seeds the second year of growth and is usually grown as an annual for the fleshy root and young leaves. The Beta vulgaris 
has three basic varieties: chard, grown specifically for its leaves; beets, grown for its bulbous root, with edible leaves (with varieties in white, yellow and red roots); and sugar beets, grown for making sugar from the long, thick root. The beet is a root vegetable with purple-green variegated leaves. It has either a round taproot with minimal secondary roots, or in the case of the sugar beet, a long carrot-like root with minimal secondary roots. The young plants, which are generally thinned by hand are good to eat as young leaves (tasting somewhat like spinach).

The beet is propagated by seed (clusters holding from three to five seeds). Therefore, it is necessary to thin the beets when they are young. The seeds will germinate in five to ten days in temperatures from $55^{\circ} \mathrm{F}-80^{\circ} \mathrm{F}$.

Commercial indicators are expensive and some of them have toxic effects on users and can also cause environ-mental pollution. For these reasons there has been an increasing interest in searching for alternative sources of indicators from natural origins. These alternatives would be cheaper, more available, simple to extract, less toxic to users and environmentally friendly. Volumetric analysis is one of the key quantitative techniques used to analytically determine both inorganic and organic acid interaction with strong or weak acids and bases in raw materials, intermediates and finished products for quality assurance purposes. This is accomplished via the use of appropriate weak organic dyes or acids $\mathrm{pH}$ indicators. Most $\mathrm{pH}$ indicators are either weak organic acids or bases dyes which accept or donate electrons. The change in color at a marginal range is attributed to their acidity or basicity properties. Although there are automated titration apparatus that determine the equivalent points between reacting species, indicators are still needed for teaching and research laboratories for simple titration

Flavanoids are colored compounds that can be isolated from various parts of plants like flowers, fruits and are $\mathrm{pH}$ sensitive. Therefore it has been hypothesized that the fruit extract could be utilized as an indicator for different types of acid base titrations. The pulps of the fruit are $\mathrm{pH}$ sensitive and give different colors in acidic condition (pink) and basic condition (greenish yellow). The equivalence points obtained by using fruit extract matched with the equivalence points obtained by standard indicators.

Flavones are soluble in water and alcohol and can be extracted by chopping and macerating the plant material, soaking it for a few minutes in hot water or rubbing with alcohol.

Colours of substances make the world a wonderful place. Because of the colours and structures; flowers, plants, animals, and minerals show their unique characters. There are various organic and inorganic compounds responsible for natural colours. Some of the organic compounds i.e. flavonoids, flavonols, acylated flavonoids, anthocyanins, glucosylated acylated anthocyanin, quinines, imines, polymethines, napthaquinones, anthraquinonoids, indigoids; dihydropyrans diarylmethanes carotene etc. imparts colours to the flower. Among them anthocyanidins and flavones are main.

The world has become aware of environmental issue in recent years. Synthetic compounds are highly polluting, hazardous and much more costly. Researchers are working in the field of natural products extensively as they are less hazardous, low cost, easily available, and eco-friendly.

\section{REVIEW OF LITERATURE}

Natural indicators have been extracted from Hibiscus (red species), Bougainvillea and rose flowers. Several authors have reported on the effectiveness of natural indicators in acid-base titrations e.g. Nerium odorum Thespesia populnea extract used as indicators; Morus alba linn fruit extract indicator and Ixora coccinea, Datura stramonium, Sun flower (Helianthus annus), pride of Barbados (Caesalpinia pulcherrima) and rail creeper (Ipomoea palmate) flower petal 
extracts . The natural indicator sources investigated in these papers have been extracted and prepared using ethanol, water, or methanol.

\section{METHODOLOGY}

\section{Plant materials}

The collection of fresh beetroot from local market of Narsingarh Madhya Pradesh, India. It was then authenticated at Department of Botany, P.G. College.

\section{Reagents}

Reagents of analytical grade were used. Sodium hydroxide, ammonia, hydrochloric acid, ethanoic acid and phenolphthalein were obtained from Department of Chemistry Gyanodaya Vidya Mandir, Narsingarh. The reagents and volumetric solutions were prepared as per Indian pharmacopeia IP 1996.

\section{Glass wares}

Burettes, pipettes etc were calibrated as per the procedures given in Indian pharmacopeia IP 1996. Preparation of root extract

$1 \mathrm{~g}$ fresh root of golden beet were extracted with warm water for 15 minutes and the aqueous extract separate and were maintained.

\section{RESULTS}

Table 1a: Titration of $\mathrm{HCl}$ against $\mathrm{NaOH}$ using aqueous golden root beet flower extract indicator.

\begin{tabular}{|c|c|c|c|c|}
\hline \multirow[t]{2}{*}{ S No } & \multirow[t]{2}{*}{ Vol of acid (ml) } & \multicolumn{2}{|c|}{ Burette reading } & \multirow{2}{*}{$\begin{array}{l}\text { Volume } \\
\text { titrant } \\
\text { mean }=£ x / n\end{array}$} \\
\hline & & Initial (ml) & Final (ml) & \\
\hline 1 & 10.0 & 0.0 & 9.6 & \multirow[t]{5}{*}{9.7} \\
\hline 2 & 10.0 & 0.0 & 9.7 & \\
\hline 3 & 10.0 & 0.0 & 9.8 & \\
\hline 4 & 10.0 & 0.0 & 9.7 & \\
\hline 5 & 10.0 & 0.0 & 9.7 & \\
\hline
\end{tabular}

Table 1b: Titration of $\mathrm{HCl}$ against $\mathrm{NaOH}$ using Phenolphthalein indicator

\begin{tabular}{|c|c|c|c|c|}
\hline \multirow[t]{2}{*}{ S No } & \multirow[t]{2}{*}{ Vol of acid (ml) } & \multicolumn{2}{|c|}{ Burette reading } & \multirow{2}{*}{$\begin{array}{l}\text { Volume of } \\
\text { titrant }(\mathrm{mL}) \\
\text { mean }=£ x / n\end{array}$} \\
\hline & & Initial (ml) & Final (ml) & \\
\hline 1 & 10.0 & 0.0 & 9.6 & \multirow[t]{5}{*}{9.7} \\
\hline 2 & 10.0 & 0.0 & 9.7 & \\
\hline 3 & 10.0 & 0.0 & 9.8 & \\
\hline 4 & 10.0 & 0.0 & 9.7 & \\
\hline 5 & 10.0 & 0.0 & 9.7 & \\
\hline
\end{tabular}

Table 2a: Titration of $\mathrm{HCl}$ against $\mathrm{NH} 3$ using aqueous golden beet root extract indicator.

\begin{tabular}{|c|c|c|c|c|}
\hline \multirow[t]{2}{*}{ S No } & \multirow[t]{2}{*}{ Vol of acid $(\mathrm{ml})$} & \multicolumn{2}{|c|}{ Burette reading } & \multirow{2}{*}{$\begin{array}{l}\text { Volume } \\
\text { titrant } \quad(\mathrm{mL}) \\
\text { mean }=£ x / n\end{array}$} \\
\hline & & Initial (ml) & Final $(\mathrm{ml})$ & \\
\hline
\end{tabular}




\begin{tabular}{|l|l|l|l|l|}
\hline & & & & \multirow{2}{*}{} \\
\cline { 1 - 4 } 1 & 10.0 & 0.0 & 9.5 & \\
\cline { 1 - 4 } 2 & 10.0 & 0.0 & 9.4 & \\
\cline { 1 - 3 } 4 & 10.0 & 0.0 & 9.6 & \\
\cline { 1 - 4 } 5 & 10.0 & 0.0 & 9.5 & \\
\hline
\end{tabular}

Table 2b: Titration of $\mathrm{HCl}$ against NH3 using Phenolphthalein indicator

\begin{tabular}{|c|c|c|c|c|}
\hline \multirow[t]{2}{*}{ S No } & \multirow[t]{2}{*}{ Vol of acid (ml) } & \multicolumn{2}{|c|}{ Burette reading } & \multirow{2}{*}{$\begin{array}{l}\text { Volume of } \\
\text { titrant }(\mathrm{mL}) \\
\text { mean }=£ \times x / n\end{array}$} \\
\hline & & Initial (ml) & Final (ml) & \\
\hline 1 & 10.0 & 0.0 & 9.5 & \multirow[t]{5}{*}{9.5} \\
\hline 2 & 10.0 & 0.0 & 9.5 & \\
\hline 3 & 10.0 & 0.0 & 9.6 & \\
\hline 4 & 10.0 & 0.0 & 9.5 & \\
\hline 5 & 10.0 & 0.0 & 9.4 & \\
\hline
\end{tabular}

Table 3a: Titration of Acetic acid against $\mathrm{NaOH}$ using aqueous golden beet root extract indicator.

\begin{tabular}{|c|c|c|c|c|}
\hline \multirow[t]{2}{*}{ S No } & \multirow[t]{2}{*}{ Vol of acid (ml) } & \multicolumn{2}{|c|}{ Burette reading } & \multirow{2}{*}{ 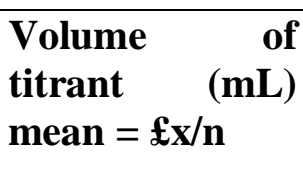 } \\
\hline & & Initial (ml) & Final (ml) & \\
\hline 1 & 10.0 & 0.0 & 9.6 & \multirow[t]{5}{*}{9.7} \\
\hline 2 & 10.0 & 0.0 & 9.7 & \\
\hline 3 & 10.0 & 0.0 & 9.8 & \\
\hline 4 & 10.0 & 0.0 & 9.7 & \\
\hline 5 & 10.0 & 0.0 & 9.7 & \\
\hline
\end{tabular}

Table 3b: Titration of Acetic acid against $\mathrm{NaOH}$ using Phenolphthalein indicator.

\begin{tabular}{|l|l|l|l|l|}
\hline S No & Vol of acid $(\mathrm{ml})$ & Burette reading & $\begin{array}{l}\text { Volume } \\
\text { titrant } \\
\text { mean }=\mathbf{e x} / \mathbf{m L}\end{array}$ \\
\cline { 3 - 4 } & & Initial $(\mathrm{ml})$ & Final $(\mathrm{ml})$ & \\
\hline 1 & & & & \\
\hline 2 & 10.0 & 0.0 & 9.6 & \\
\hline 3 & 10.0 & 0.0 & 9.6 & \\
\hline 4 & 10.0 & 0.0 & 9.7 & \\
\hline 5 & 10.0 & 0.0 & 9.4 & \\
\hline
\end{tabular}

Table 4a: Titration of Acetic acid against $\mathrm{NaOH}$ using aqueous golden beet root extract indicator

\begin{tabular}{|l|l|l|l|l|}
\hline S No & Vol of acid (ml) & \multicolumn{2}{|l|}{ Burette reading } & $\begin{array}{l}\text { Volume of } \\
\text { titrant } \\
\text { mean }=£ \mathbf{m L} / \mathbf{m}\end{array}$ \\
\cline { 3 - 5 } & & Initial $(\mathrm{ml})$ & Final $(\mathrm{ml})$ & \\
& & & \\
\hline
\end{tabular}




\begin{tabular}{|l|l|l|l|l|}
\hline 1 & 10.0 & 0.0 & 9.7 & \multirow{2}{*}{9.7} \\
\hline 2 & 10.0 & 0.0 & 9.7 & \\
\cline { 1 - 4 } & 10.0 & 0.0 & 9.8 \\
\cline { 1 - 3 } & 10.0 & 0.0 & 9.7 & \\
\hline
\end{tabular}

Table 4b: Titration of Acetic acid against NH3 using Phenolphthalein indicator

\begin{tabular}{|c|c|c|c|c|}
\hline \multirow[t]{2}{*}{ S No } & \multirow[t]{2}{*}{ Vol of acid (ml) } & \multicolumn{2}{|c|}{ Burette reading } & \multirow{2}{*}{$\begin{array}{l}\text { Volume of } \\
\text { titrant }(\mathrm{mL}) \\
\text { mean }=£ \times / n\end{array}$} \\
\hline & & Initial $(\mathrm{ml})$ & Final $(\mathrm{ml})$ & \\
\hline 1 & 10.0 & 0.0 & 9.9 & \multirow[t]{5}{*}{9.9} \\
\hline 2 & 10.0 & 0.0 & 10.0 & \\
\hline 3 & 10.0 & 0.0 & 9.9 & \\
\hline 4 & 10.0 & 0.0 & 9.8 & \\
\hline 5 & 10.0 & 0.0 & 9.9 & \\
\hline
\end{tabular}

\section{EXPERIMENTAL PROCEDURE}

The root of golden were separated and cleaned with distilled water. It was then cut to small pieces and transferred to a clean beaker. $100 \mathrm{ml}$ of distilled water was taken in another beaker and gently warmed and poured to the petals and kept aside for 15 minutes. The extract was then poured carefully to a glass container through a funnel and stored aside separately without exposing to direct sunlight.

\section{Test for color change}

$0.1 \mathrm{ml}$ of the extract was added to $25 \mathrm{ml}$ each of buffer solutions of $\mathrm{pH}$ ranging from 1 .

\section{Titrations}

$0.1 \mathrm{ml}$ of the extract was added as indicator for each titration type- strong acid against strong base, strong acid against weak base. Weak acid against strong base and weak acid against weak base and the trials were repeated 5 times to check the precision. The titrations were again performed using phenolphthalein indicator as standard and the results obtained were compared with the results of titrations using plant extract indicator. The results for titrations are depicted in the tables 1a to $4 \mathrm{~b}$.

The equivalence point of the titrations using the flower extract either coincided or almost reached close to the equivalence point using the standard indicator, phenolphthalein for all the titrations. In several cases it proved to be more reliable than the standard indicator and gave sharp color change at equivalence point. It was also observed that the extract act reversibly and gave sharp color change in both the directions.

Thus the study helped to realize that the root pigment of golden beet could be effectively used as a substitute to the presently existing indicators owing to the factors like simple preparation, good performance and accurate and precise results. 


\section{REFERENCES}

1. Patil M.V. ,Jadhav R.L. (2012) Use of Phyllanthus reticulatus Fruit Extract as a Natural Indicator in acid base titration International Journal of Pharmacy and Pharmaceutical Sciences Vol 4, Suppl 1, 2012

2. Pathan Mohd Arif Khan, Mazahar Farooqui (2011) Analytical Applications of Plant Extract as Natural pH Indicator: A Review J Adv Scient Res, 2011; 2(4): 20-27

3. Prashant Thote and Mansi Khare (2013) Investigation of a Simple and Cheap Source of a Natural Indicator for Acid-Base Titration: Effect of System Conditions on Natural Indicators Journal of Research,Extension and Development (accepted for publication)

4. Prashant Thote and Medha Singh (2013) Investigation of a Simple and Cheap Source of a Natural Indicator for Acid-Base Titration: A small step for Eco-Friendly Environment Journal of Research, Extension and Development vol.02 no 03 pp 54-65

5. Prashant Thote (2013) Isolation of herbal acid-base indicator from the seeds of Tagetes erecta Journal of Research, Extension and Development vol.02 no 00 pp 45-51

6. Prashant Thote Investigation of a simple an chef source of a natural Indicator for AcidBase Titration :Effect of system Conditions on Natural Indicators (Unpublished work)

7. Sajin Kattuvilakam Abbas (2,012) Study of acid-base indicator property of flowers of Ipomoea biloba International Current Pharmaceutical Journal 2012, 1(12): 420-422. 